\title{
T.T. CLOETE: WENNER VAN DIE LOUIS LUYT-PR YS VIR 1982
}

Prof. T.T. (Gloetc, hoof van dic departement Afrikaans-Nederlands aan dic PU vir (.HO, het in die herfs dic Louis Luyt-Prys vir Afrikaanse letterkunde vir 1982 ontvang. Die toekenning is veral gemaak op grond van sy tweede bundel, Jukstaposisie, wat allerwee: baie goed ontvang is, nadat sy eerste bundel, Angelliera, ook sterk vir hicrdic prys oorwerg is. Jukstaposisie het in 1982 by Tafelberg-uitgewers verskyn en kos R 10,50 plus $A$ VB. Hierloy word twee gedigte uit hierdie bundel oorgedruk.

\section{Skouspel I}

vanaf die glansende dun horings en dic gesig puntig verfynd uit oor die lig geboë rug tot in die stertkwassic spigtig

gelig af in dic glasbreckbaar dun bene pronk waaierhaar

die springlook nacl met dic speer se vaart wip met die haarveer

sc spanning hoepel socpel

onder die Ireu majest eitlik veilig en gevrecs pragtig

onder sy gewig

vouknakval

die springbok met 'n knapknal

breck hy die bene en rug en maak prooi van elegansic wat argeloos mooi

is lê en spartel

voor die gewelddadige mooi wat aanskoulik martel 


\title{
Skouspel II
}

liy is 'n fier

geweldenaar hy jag

al met dic lewensgeurige wind langs

in dic nag

dic triomfantlike tier

sy sicrlikhcid swecp) lyy slangslank

in 'n fraai kurwe van die kop af lank

uit tot in die stertkwas deur dic socpel rug

sy bevrediging krul hy oor sy vangs

uit sovecl venynige prag

is daar sovecl angs

voor hom sovecl magtelose vlug

\author{
Uit: T.T. Cloete \\ Jukstaposisic \\ Tafelberg-uitgewers \\ 1.982
}

